\title{
PROGRAM JAM WAJIB BELAJAR DALAM MEMBENTUK CIVIC DISPOSITION WARGA NEGARA
}

\author{
Oleh : \\ Nastiti Mufidah \\ e-mail: n4f4zmoefyd@gmail.com \\ Program Magister Pendidikan Kewarganegaraan, Sekolah Pascasarjana, Universitas \\ Pendidikan Indonesia \\ Jl. Dr Setiabudi No. 229, Bandung, Jawa Barat, Indonesia
}

\begin{abstract}
The purpose of this research to analyze the formation of civic disposition through compulsory Hours Learning Program, as well as knowing the character of the citizens who were able to form through the Compulsory program clock. Informants in this research is a community in Mojokerto city. Qualitative approach with case study method used in this study. Furthermore, the data collection techniques used interviews, observations and questionnaires. The results in this study indicate that the Compulsory Education Program Hours proven capable of forming civic disposition citizens. Civic disposition can be formed based on the results of this study the character of discipline and care, while other characters such as responsibility and tolerance still can't set up perfectly.
\end{abstract}

Keywords: Compulsory Hours Learning Program, Civic Disposition, Citizen

\section{PENDAHULUAN}

\subsection{Latar Belakang}

Belajar dengan disiplin dan terarah akan mampu menghindarkan diri dari rasa malas serta memunculkan kegairahan anak untuk belajar, yang pada akhirnya akan dapat meningkatkan daya kemampuan belajar anak. Seorang anak yang memiliki disiplin belajar akan menunjukkan kesiapannya dalam mengikuti pelajaran di kelas, datang tepat waktu, memperhatikan guru, menyelesaikan tugas tepat waktu dan memiliki kelengkapan belajar seperti buku dan alat-alat belajar lainnya. Oleh karena itu, dapat disimpulkan bahwa betapa pentingnya disiplin belajar di sekolah maupun di luar sekolah guna menunjang prestasi belajar yang diperoleh oleh anak.

Namun realitanya kedisiplinan anak dalam belajar di rumah dapat dikatakan sangatlah rendah. Hal ini dapat diketahui dari tugas rumah yang diberikan oleh guru yang sering tidak dikerjakan karena lupa kalau tidak diingatkan oleh orang tuanya. Selain itu juga kerap tidak mengerjakan tugas atau PR, maupun lupa tidak membawa buku tugas yang sudah diselesaikan. Bahkan tidak jarang, anakanak saat pulang dari sekolah tidak langsung pulang ke rumah, tetapi bermain dengan teman-temannya terlebih dahulu. Hal itulah yang kerap mengakibatkan anak mendapat nilai yang tidak memuaskan atau jelek dan pekerjaan rumah mereka tidak dapat terselesaikan dengan baik.

Pernyataan tersebut didukung oleh hasil riset yang dilakukan Weisner, dkk. (2001, hlm. 20) dari Universitas California di Los Angeles yang menyatakan bahwa pada saat para penulis menggabungkan hasil temuan mereka untuk memeriksa kegiatan para anak saat berada di rumah dan di sekolah diperoleh kesimpulan bahwa, anak-anak dengan prestasi sekolah yang lebih tinggi cenderung lebih terlibat 
dalam tugas-tugas, pekerjaan rumah, kegiatan sosial serta berbagai hobi yang diarahkan demi orientasi masa depan. Sedangkan anak-anak dengan tingkat prestasi yang lebih rendah, cenderung terlibat dalam kegiatan menonton televisi, bermain video game, bermain soliter, serta lebih banyak menghabiskan waktunya untuk sekedar beristirahat.

Lebih lanjut menurut Fried (2011, hlm. 112) pentingnya pembelajaran disiplin di berbagai Negara dapat dipengaruhi oleh beragam budaya yang berlaku di Negara tersebut. Sehingga dalam menciptakan karakter dalam hal ini karakter disiplin di Negara Indonesia, selain dapat dibentuk oleh orang tua maupun guru, namun dibutuhkan pula sebuah peraturan atau kebijakan yang mendukung terciptanya karakter sebut. Peran pemerintah dalam menanamkan pembinaan karakter disiplin, salah satunya dengan cara pencanangan berbagai kebijakan guna meningkatkan mutu pendidikan. Salah satu contohnya yakni kebijakan yang diambil oleh Pemkot Mojokerto terkait Program Jam Wajib Belajar.

Program Jam Wajib Belajar dimulai sejak tahun 2009, peraturannya yakni Pemerintah Kota Mojokerto melarang pelajar di Kota Mojokerto pada pukul 18.00 hingga 19.00 WIB, bermain atau menonton siaran televisi. Gambaran dari pelaksanaan program tersebut adalah setiap pukul $18.00 \mathrm{~s} / \mathrm{d} 19.00$ WIB para anak usia pelajar wajib belajar yaitu dari usia dini hingga perguruan tinggi diwajibkan untuk belajar. Orang tua difungsikan sebagai pengawal internal sedangkan sebagai pengawas eksternal atau di luar adalah ketua RT sebagai Satgas Wajib Belajar.

Namun berdasarkan berbagai hasil survey dan observasi awal terkait Program Jam Wajib Belajar ini, menunjukkan hasil dan tanggapan yang beragam sehingga harus ada bukti konkret yang dapat digunakan dalam menjawab dan menguatkan berbagai statemen tersebut. Oleh karena itu penelitian ini ditujukan guna menjawab pertanyaan dan mengkaji hasil data terkait dengan pembentukan civic disposition warga Negara melalui Program Jam Wajib Belajar serta berbagai civic disposition yang mampu dibentuk melalui Program Jam Wajib Belajar.

\subsection{Rumusan Masalah dan Tujuan Penelitian}

Berdasarkan latar belakang masalah di atas, maka rumusan masalah dalam penelitian ini yakni,

1. Bagaimana cara membentuk civic disposition warga Negara melalui Program Jam Wajib Belajar?

2. Civic disposition apa saja yang dapat dibentuk melalui Program Jam Wajib Belajar?

Dengan berdasar pada kedua rumusan masalah tersebut, maka tujuan dari penelitian yakni,

1. Untuk mengetahui lebih lanjut terkait pembentukan civic disposition warga Negara melalui Program Jam Wajib Belajar.

2. Untuk menganalisis civic disposition yang dapat dibentuk melalui Program Jam Wajib Belajar?

\subsection{Metode Penelitian}

Metode studi kasus dalam pendekatan kualitatif digunakan dalam penelitian ini. Metode studi kasus ini digunakan untuk mengungkap data atau informasi sebanyak mungkin mengenai pembentukan civic disposition warga Negara melalui Program Jam Wajib Belajar. Narasumber dalam penelitian ini terbagi menjadi tiga kelompok yakni, pemerintah, warga/orang tua, dan pelajar. Penelitian ini dilakukan di Kota Mojokerto karena Pemerintah Daerah Kota Mojokerto adalah lembaga Pemerintahan daerah pertama yang menggagas Program Jam Wajib Belajar, yakni sejak dikeluarkannya Perwali tahun 2009. Penelitian ini 
dilakukan selama dua bulan dengan menggunakan teknik wawancara, observasi dan kuesioner. Selanjutnya berbagai data yang dihasilkan dari ketiga teknik tersebut kemudian dianalisis dengan menggunakan model dari Milles dan Huberman. Teknis analisis tersebut terdiri dari reduksi data, penyajian data, dan verifikasi data (Milles dan Haberman, 2007). Data yang berhasil diperoleh kemudian divalidasi menggunakan teknik triangulasi sumber dan teknik pengumpulan data.

\subsection{Kerangka Teori}

Karakter yang baik adalah berisi kebajikan. Kebajikan seperti kejujuran, keberanian akan keadilan, dan kasih sayang adalah disposisi untuk berperilaku dalam cara yang baik secara moral. Hal tersebut merupakan kualitas manusia yang baik secara obyektif. Ini ditegaskan oleh masyarakat dan agama di seluruh dunia. Orang yang secara intrinsik "baik" memiliki klaim atas hati nurani. Kebajikan melampaui waktu dan ekspresi budaya yang berbeda. Kebajikan secara objektif yang baik bukanlah merupakan preferensi subjektif (Lickona, 2004, hlm. 6-7). Berdasarkan pemaparan di atas dapat dikemukakan bahwa pengertian karakter adalah serangkaian ciri-ciri psikologis manusia yang melandasi perilakunya berdasarkan norma-norma dalam masyarakat yang berupa nilai-nilai kebajikan sehingga tertanam dalam diri setiap manusia dan dianggap baik dalam masyarakat.

Pengertian pendidikan karakter menurut Cholisin, (2011, hlm. 3) adalah suatu sistem penanaman nilai-nilai perilaku (karakter) kepada warga sekolah yang meliputi pengetahuan, kesadaran atau kemauan, dan tindakan untuk melaksanakan kemauan, dan tindakan untuk melaksanakan nilai-nilai, baik terhadap Tuhan Yang Maha Esa (YME), diri sendiri, sesama, lingkungan, maupun kebangsaan sehingga menjadi insan kamil. Menurut Zamroni, (2011, hlm. 159) menyatakan bahwa pendidikan karakter merupakan proses untuk mengembangkan pada diri setiap peserta didik kesadaran sebagai warga bangsa yang bermartabat, merdeka dan berdaulat dan berkemauan untuk menjaga dan mempertahankan kemerdekaan dan kedaulatan tersebut.

Pendidikan karakter yang menjadi misi pendidikan yakni meliputi seluruh aspek yang dibutuhkan demi terciptanya warga negara yang cerdas, terampil dan berkarakter sesuai dengan amanat UndangUndang Dasar 1945, yaitu warga negara yang cerdas berdasarkan substansi pengetahuan Kewarganegaraan (civic knowledge), terampil berdasarkan substansi keterampilan kewarganegaraan (civic skill), dan warga negara yang berkarakter berdasarkan substansi karakter kewarganegaraan (civic dispositions). Ketiga aspek inilah yang akan dibangun dalam diri warga negara Indonesia, yang nantinya diharapkan mampu berkembang menjadi sebuah penalaran yang akan terwujud dalam perilaku bermasyarakat, berbangsa, dan bernegara sesuai dengan cita-cita membangun masyarakat madani dengan kekuatan pemberdayaan warga negara (citizen empowerment), namun tetap masih dengan materi karakter yang bersumber pada nilai-nilai yang ada dalam masyarakat bangsa Indonesia.

Beberapa teori dalam pendidikan digunakan dalam analisis hasil dari penelitian ini yang diantaranya adalah teori behaviorisme, teori harapan dan teori informasi. Teori behaviorisme yang diungkap oleh Skinner (1953) berasumsi bahwa behaviour ditentukan oleh keinginan untuk mendapatkan penguatan positif dan untuk menghindari penguatan negatif (dalam Austin dan Omomia, 2014, hlm. 174). Lebih lanjut Griffith dan Hamza (2006) menyatakan bahwa behaviourisme terutama berkaitan dengan konsekuensi dari perilaku yang merupakan respon atau perilaku nyata dan dapat diamati. 
Lima langkah mendasar memandu proses perubahan perilaku di bawah pedoman behaviorisme:

1. Tetapkan tujuan perilaku,

2. Tentukan reinforcers yang tepat,

3. Pilih prosedur untuk mengubah perilaku,

4. Melaksanakan prosedur dan hasil rekaman,

5. Evaluasi kemajuan dan merevisi seperlunya.

Selanjutnya terdapat metode Reward and Punishment yang juga merupakan suatu bentuk penguatan positif dari teori behavioristik. Reward dan Punishment juga dicetuskan oleh Skinner, yang di ambil dari hasil percobaan yang kemudian dikenal dengan istilah Operant Conditioning (pembiasaan perilaku respon) yakni, "tingkah laku pada dasarnya merupakan fungsi dari konsekuensi tingkah laku itu sendiri, apabila munculnya tingkah laku diikuti dengan sesuatu yang menyenangkan (reward), maka tingkah laku tersebut cenderung untuk diulang. Sebaliknya, jika munculnya tingkah laku diikuti dengan sesuatu yang tidak meyenangkan (punishment), maka tingkah laku tersebut cenderung tidak akan diulang." (Maksum dalam Sardiman, 2007, hlm. 9)

Terkait dengan metode Reward and Punishment, berbagai disiplin ilmu telah menunjukkan hubungan antara perilaku sosial dan perilaku modulasi oleh reward atau punishment (Hardin dkk. 2005, hlm. 699). Sama halnya dengan pendapat dari Nassima dan Souheyla (2014, hlm. 64) yang mengungkapkan bahwa individu akan mengungkapkan tanggapan yang maladaptif (umpan balik negatif) terhadap hukuman (punishman) dan tanggapan hyposensitive (kritik yang baik) terhadap penghargaan (reward).

Selanjutnya, teori harapan adalah teori yang menekankan peran dari hambatan, stressor, dan emosi. Dimana, ketika individu menjumpai hambatan yang menghalangi pencapaian tujuan, individu tersebut akan menilai kondisi tersebut sebagai sumber stres. Dalam bukunya Snyder (1994, hlm. 5-8) mendefinisikan harapan sebagai, "mental willpower plus waypower for goals". Willpower, in this definition is "the driving force to hopeful thinking". It is a sense of mental energy that helps move a person toward a goal. Waypower, the second component in the hope equation, is the mental capacity used to find a way to reach your goals. It reflects the mental plans or road maps that guide hopeful thought".

Berdasarkan definisi harapan di atas, maka dapat siketahui bahwa harapan terdiri dari komponen willpower dan waypower untuk mencapai tujuan (goals). Kedua komponen tersebut bersifat timbal balik, saling melengkapi dan berkorelasi positif. Menurut teori harapan dari Snyder tersebut harapan merefleksikan persepsi individu terhadap kemampuan untuk mendefinisikan tujuan dengan jelas, berinisiatif dan mempertahankan motivasi untuk menggunakan berbagai strategi (willpower thinking), dan mengembangkan strategi yang spesifik untuk mencapai tujuan tersebut (waypower thinking).

Berdasarkan postulat teori harapan tersebut, dapat disimpulkan bahwa emosi positif dihasilkan dari persepsi mengenai keberhasilan pencapaian tujuan. Sebaliknya emosi negatif mencerminkan kegagalan pencapaian tujuan, baik yang mengalami hambatan ataupun tidak mengalami hambatan. Oleh karena itu, persepsi mengenai keberhasilan pencapaian tujuan akan mendorong munculnya emosi positif dan negatif. Yang pada akhirnya emosi ini bertindak sebagai reinforcing feedback. (Snyder, Shorey, dkk. 2002).

Dari pemaparan tersebut dapat dipahami bahwa harapan merupakan sesuatu yang dapat dibentuk dan dapat digunakan sebagai langkah untuk perubahan. Perubahan yang menguntungkan dapat menyebabkan 
individu mencapai hidup yang lebih baik. Setiap individu memiliki kemampuan untuk membentuk harapan karena mereka memiliki komponen dasar dalam kemampuan kognitif yang diperlukan untuk menghasilkan pemikiran-pemikiran yang berhubungan dengan harapan.

Teori ketiga yang digunakan dalam penelitian ini adalah teori komunikasi, teori ini melihat komunikasi sebagai fenomena mekanistis, matematis, dan informatif. Komunikasi digunakan sebagai transmisi pesan dan bagaimana transmitter menggunakan saluran dan media komunikasi. Ini merupakan salah satu contoh gamblang dari mazhab proses yang mana melihat kode sebagai sarana untuk mengonstruksi pesan dan menerjemahkannya (encoding dan decoding). (Shannon, 1948, hlm. 379)

Saat ini komunikasi merupakan suatu kebutuhan yang sangat fundamental bagi seseorang dalam hidup bermasyarakat. Hal yang mendorong manusia berkomunikasi dengan manusia lain adalah kebutuhan untuk mempertahankan kelangsungan hidupnya dan kebutuhan untuk menyesuaikan diri dengan lingkungannya. Sementara menurut Harold D Lasswell (dalam Cangara, 2005, hlm. 2), menyebutkan ada tiga fungsi dasar perlunya manusia berkomunikasi yaitu:

1) Hasrat manusia untuk mengontrol lingkungannya. Melalui komunikasi manusia dapat mengetahui peluang yang ada untuk dimanfaatkan, dipelihara atau dihindarkan di sekitar lingkungannya.

2) Upaya manusia untuk dapat beradaptasi dengan lingkungannya.

3) Upaya untuk melakukan transpormasi warisan sosialisai

Jadi dengan demikian dapat disimpulkan bahwa komunikasi tidak dapat dipisahkan dari kehidupan manusia baik sebagai individu maupun masyarakat. Komunikasi diperlukan untuk mengatur tatakrama pergaulan antar manusia. Dalam penelitian ini teori informasi (Mathematical Theory of Communication) digunakan untuk menganalisis semua elemen pelaku dan bentuk komunikasi serta proses yang terjadi dalam pelaksanaan Program Jam Wajib Belajar. Pelaku komunikasi mencakup warga Kota Mojokerto, Pemerintah Mojokerto yang meliputi Walikota, Wawalikota, Ketua Dinas Pendidikan, Sekda, Pokja, Posko, Satgas, serta Tim Motivator Program Jam Wajib Belajar.

\section{HASIL DAN PEMBAHASAN \\ 2.1. Pembentukan Civic Disposition Warga Negara Melalui Program Jam Wajib Belajar.}

Terkait dengan pertanyaan apakah Program Jam Wajib Belajar ini dapat membentuk civic disposition, data yang diperoleh oleh peneliti menunjukkan hasil bahwa tujuan awal diberlakukan program Jam Wajib Belajar adalah untuk menciptakan lingkungan berpendidikan, Drs. KH Mas'ud Yunus sebagai pencetus program ini juga mengungkapkan bahwa latar belakang program ini dikeluarkan adalah guna membangun Sumber Daya Manusia di Kota Mojokerto yang notabene adalah kota dengan luas wilayah terkecil di seluruh Indonesia (lihat Lokasi Penelitian). Sehingga dalam kata lain, Drs. KH Mas'ud Yunus berusaha membuktikan bahwa ungkapan dari Kneedler, dkk (2000, hlm. 381) tidak berlaku di Kota Mojokerto ini. Dimana hasil penelitian dari Kneedler, dkk. menyimpulkan bahwa,

"We find that higher capacity governments are able to achieve better human resources outcomes, and that more unionized governments and those that lack a senior professional administrative officer generally have lower human resources management capacity." Apabila diperhatikan secara mendalam mengenai latar belakang dibentuknya Program Jam Wajib Belajar ini 
lebih sesuai dengan ungkapan yang diungkapkan oleh Suwarno (1985 hlm. 65) dimana pendidikan berlangsung dalam tiga lingkungan pendidikan, yaitu dalam lingkungan keluarga, di lingkungan sekolah, dan di dalam masyarakat, ada yang secara formal, informal dan ada pula secara nonformal. Lebih lanjut ketiga lingkungan pendidikan tersebut oleh $\mathrm{Ki}$ Hadjar Dewantara disebut sebagai Tri Pusat Pendidikan. Konsep Tri Pusat Pendidikan tersebut mempunyai maksud bahwa terdapat tiga pusat lingkungan pendidik yang secara bertahap dan terpadu bertanggung jawab terhadap pendidikan bagi generasi mudanya.

Ketiga pusat penanggung jawab pendidikan ini dituntut agar mampu melakukan kerja sama diantara mereka baik secara langsung maupun tidak langsung, dengan cara saling menopang serta membantu kegiatan yang sama secara bersama-sama. Dengan kata lain, kegiatan mendidik yang dilakukan orang tua terhadap anak juga juga dilakukan oleh sekolah dengan memperkuatnya serta dikontrol masyarakat sebagai lingkungan sosial anak. Karena dalam hal ini masyarakat merupakan tempat atau unsur yang sangat berperan penting dalam pendidikan. Hal tersebut sesuai dengan ungkapan Maunah (2009) dan Ihsan (2007) dimana lembaga-lembaga kemasyarakatan dan atau kelompok sosial dalam masyarakat, baik langsung maupun tidak, ikut mempunyai peran dan fungsi edukatif. Selanjutnya terkait dengan bagaimana cara yang digunakan dalam membentuk civic disposition warga Negara melalui Program Jam Wajib Belajar, dalam menjawab pertanyaan tersebut peneliti menggunakan pendapat dari dua tokoh konstruksi sosial terkait dengan proses sosialisasi. Kedua tokoh tersebut yakni Berger dan Luckman (Pramitha, 2010 hlm. 18) yang mengungkapkan bahwa agar sosialisasi dapat berjalan lancar, tertib dan berlangsung terus menerus, maka terdapat dua tipe sosialisasi yakni:
1) Formal, sosialisasi tipe ini terjadi melalui lembaga-lembaga yang berwenang menurut ketentuan yang berlaku dalam negara, seperti pendidikan di sekolah dan pendidikan militer.

2) Informal, sosialisasi tipe ini terdapat di masyarakat atau dalam pergaulan yang bersifat kekeluargaan, seperti antara teman, sahabat, sesama anggota klub, dan kelompokkelompok sosial yang ada di dalam masyarakat.

Apabila kedua tipe sosialisasi yang diungkapkan oleh Berger dan Luckman tersebut digunakan untuk mengkaji mengenai teknik sosialisasi yang digunakan oleh Pemerintah Kota Mojokerto guna mensosialisasikan Program Jam Wajib Belajar, maka diperoleh kesimpulan bahwa pemerintah Kota Mojokerto telah menggunakan kedua teknik tersebut dengan baik. Kesimpulan ini didukung oleh berbagai data yang ditemukan peneliti di lapangan melalui proses wawancara, studi dokumentasi dan observasi, dimana berdasarkan hasil triangulasi data yang digunakan oleh peneliti, peneliti mendapatkan kesimpulan bahwa teknik sosialisasi Program Jam Wajib Belajar yang digunakan Pemerintah Kota Mojokerto kepada masyarakat dilakukan dengan tujuh cara yakni;

1) Pengadaan Kalender;

2) Gebyar Seni dan Anugrah Prestasi Pendidikan;

3) Pembinaan anggota Posko PKMBP dan Satgas Jam Wajib Belajar;

4) Pembinaan Tim Motivator KBP;

5) Pembinaan administrasi dan organisasi Satgas Jam Wajib Belajar \& Posko PKMBP;

6) Himbauan yang disiarkan di musholamushola yang tersebar di lingkup Kota Mojokerto;

7) Penempelan stiker mengenai Program Jam Wajib Belajar di setiap rumah atau di tempat-tempat umum. 
Kesimpulan tersebut juga didukung oleh data yang diperoleh peneliti saat melakukan pengambilan data dengan menggunakan kuesioner. Berdasarkan hasil kuesioner tersebut, peneliti mendapatkan kesimpulan bahwa sebagian besar yakni 96,5\% dari narasumber yang berjumlah 29 pelajar yang saat itu berada di tiga tempat yang berbeda ini telah mengetahui tentang Program Jam Wajib Belajar yang diadakan oleh Pemerintah Kota Mojokerto. Sumber informasi yang diperoleh oleh masingmasing narasumber memang sangatlah beragam, yakni dari orang tua sebesar $28,6 \%$, dari sekolah sebesar $21,5 \%$, dari pak Rt sebesar $17,9 \%$, dari stiker $14,2 \%$, dari pemerintah $10,7 \%$, dan sisanya sebesar $17,9 \%$ berasal dari tiga sumber lain yakni saudara, masjid dan spandukspanduk yang ada dijalan.

Walaupun telah menggunakan teknik sosialisasi yang tepat, namun suatu program tidak akan dapat berjalan dengan baik jika teknik pelaksanaannya kurang tepat. Menurut Syukur (1987, hlm. 40), teknik pelaksanaan yang tepat merupakan aktifitas atau usaha-usaha yang dilaksanakan untuk melaksanakan semua rencana dan kebijaksanaan yang telah dirumuskan dan ditetapkan dengan dilengkapi segala kebutuhan, alat-alat yang diperlukan, siapa yang melaksanakan, dimana tempat pelaksanaannya dimulai dan bagaimana cara yang harus dilaksanakan. Lebih lanjut menurut penelitian yang dilakukan oleh Kwon (2014, hlm 765) menunjukkan bahwa motivasi intrinsik birokrat (misalnya, motivasi pelayanan publik) dapat mengurangi dampak negatif (disuapnya mereka) sebagai motivasi ekstrinsik.

Dari pengertian tersebut maka dapatlah ditarik suatu kesimpulan bahwa pada dasarnya pelaksanaan suatu program yang telah ditetapkan oleh pemerintah harus sejalan dengan kondisi yang ada (baik itu di lapangan maupun di luar lapangan). Selain itu kegiatan tersebut harus melibatkan berbagai unsur disertai dengan usaha-usaha dan didukung oleh alat-alat penujang. Kesimpulan yang terakhir yakni, dalam pelaksanaan suatu program juga harus didasari dengan motivasi intrinsik para birokratnya yakni guna meningkatkan pelayanan publik.

Kondisi yang mendukung, keterlibatan dan usaha dari berbagai unsur yang menunjang, serta motivasi intrinsik para birokrasi memang terbukti dapat meningkatkan struktur peluang akan keberhasilan suatu kebijakan yang berlaku. Hal tersebut menurut Berger dan Hevenstone (2016, hlm. 1) berkaitan dengan "broken windows theory", dimana "broken windows" mungkin tidak hanya dapat mendorong prilaku menyimpang, tapi juga akan melemahkan kontrol sosial. Sehingga Berger dan Hevenstone berpendapat bahwa struktur peluanglah yang pada akhirnya akan mendorong setiap individu untuk menjaga norma. Seperti yang ditunjukkan oleh fakta, dimana, "people are more likely to voluntarily pick up litter when it is closer to a trash bin."

\section{CIVIC DISPOSITION YANG DAPAT DIBENTUK MELALUI PROGRAM JAM WAJIB BELAJAR.}

Terkait dengan civic disposition apa saja yang dapat dibentuk melalui Program Jam Wajib Belajar. Berdasarkan (Kemdiknas, 2011, hlm. 8) telah teridentifikasi 18 nilai yang bersumber dari agama, Pancasila, budaya, dan tujuan pendidikan nasional. Dari ke-18 nilai tersebut, maka peneliti memperoleh data bahwa Program Jam Wajib Belajar ini yang pertama dapat membentuk karakter kedisiplinan. Dimana menurut Mar'at (1994, hlm. 92) disiplin adalah sikap perseorangan atau kelompok yang menjamin adanya kepatuhan terhadap perintah-perintah dan berinisiatif untuk melakukan suatu tindakan yang perlu seandainya tidak ada perintah. 
Berdasarkan hasil temuan data yang diperoleh peneliti di lapangan menyatakan bahwa 19 anak atau sekitar $65,5 \%$ dari jumlah keseluruhan (29 anak) telah melakukan aktifitas belajar secara intens atau sering. Selanjutnya sisanya yakni $34,5 \%$ anak masih belum melaksanakannya secara intens atau dapat dikatan mereka hanya melakukan aktifitas belajar sebanyak 1-4 kali dalam seminggu. Sehingga dapat disimpulkan bahwa karakter disiplin belajar telah terbentuk di lingkungan pelajar Kota Mojokerto. Hal ini dapat dilihat dari intensitas para pelajar dalam melakukan aktifitas belajar dalam satu minggu.

Kesimpulan tersebut didukung oleh pendapat Ningsih (2006, hlm. 62) yang menyatakan bahwa, orang yang disiplin akan hidup secara teratur, dan orang yang disiplin memiliki ciri-ciri sebagai berikut:

1) Disiplin akan membentuk perilaku yang senatiasa terbiasa tertib dan teratur.

2) Selalu menepati janji, karena orang yang disiplin akan selalu membuat jadwal kegiatan, sehingga tidak lupa untuk menepati janji.

3) Orang yang disiplin pasti akan membuat jadwal kegiatan.

4) Orang yang disiplin akan senantiasa mentaati peraturan yang berlaku.

5) Orang yang hidup disiplin akan menjalankan tugas dengan sebaikbaiknya.

Civic disposition berikutnya yang diharapkan dapat terbentuk dari Program Jam Wajib Belajar adalah tanggung jawab. Dalam hal ini peneliti mengkaitkan terbentuknya karakter tanggung jawab dari alasan pelajar melakukan aktifitas belajar saat Jam Wajib Belajar sedang berlangsung. Dan hasil yang diperoleh peneliti yakni sebesar $65,6 \%$ anak akan memperoleh sanksi baik dari ayah ataupun dari ibu jika tidak melaksanakan aktifitas belajar. Sedangkan $34,4 \%$ sisanya tidak mendapatkan sanksi walaupun tidak melaksanakan aktifitas belajar.

Berdasarkan perolehan data tersebut dapat disimpulkan bahwa tanggung jawab yang dimiliki oleh pelajar di lingkup Kota Mojokerto dapat dikatakan masih rendah. Hal tersebut dapat dibuktikan dari pengakuan para narasumber bahwa mereka akan mendapatkan sanksi saat tidak melaksanakan aktifitas belajar, sehingga dapat ditarik kesimpulan bahwa salah satu alasan para pelajar melaksanakan aktifitas belajar adalah karena takut mendapatkan sanksi terutama dari orang tua yakni ayah atau ibu. Jika kita mengacu pada pendapat yang diungkapkan oleh Rose (2003) bahwa tujuan awal disiplin belajar pada anak ada dua, yaitu membuat anak terlatih dan terkontrol dan juga mampu menumbuhkan rasa tanggung jawab dalam diri anak.

Dimana pernyataan tersebut mengandung pengertian bahwa ketika sudah berdisplin, anak dapat mengarahkan dirinya sendiri tanpa pengaruh atau pun disuruh oleh orang lain. Maka sangatlah jelas terlihat bahwa, walaupun para pelajar Kota Mojokerto telah dapat dikatakan mempunyai kedisiplinan dalam belajar, namun rasa tanggung jawab dalam diri anak masih belum terbentuk secara sempurna.

Selanjutnya civic disposition yang diharapkan dapat terbentuk dengan adanya Program Jam Wajib Belajar adalah toleransi. Toleransi yang diharapkan dapat terbentuk yakni toleransi yang dimiliki masyarakat maupun anggota keluarga lain saat anak sedang melakukan aktifitas belajar. Namun dalam kenyataannya, berdasaran data yang ditemukan di lapangan menunjukkan bahwa sebesar $62,06 \%$ pelajar mengaku bahwa masih ada anggota keluarga yang menonton televisi pada Jam Wajib Belajar. Sedangkan hanya sisanya yakni sekitar $37,96 \%$ yang mematikan televisi pada jam-jam tersebut. 
Hasil data dari kuesioner tersebut diperkuat dari hasil observasi dan studi dokumentasi yang diperoleh peneliti yang menunjukkan bahwa memang masih banyak anggota keluarga yang menonton televisi pada saat anak-anak atau anggota keluarga lain (yang masih berstatus sebagai pelajar) sedang melaksanakan aktifitas belajar. Aktivitas tersebut menurut peneliti akan mengakibat berbagai dampak negatif diantaranya dapat mengganggu konsetrasi para pelajar yang sedang belajar, bahkan akibat terburuk yang kerap timbul yakni mengakibatkan pelajar tersebut tertarik untuk ikut bersama-sama menonton televisi, sehingga meninggalkan aktifitas belajar yang dilakukannya.

Dengan data yang diperoleh tersebut, maka dapat disimpulkan bahwa sebagian besar masyarakat kota Mojokerto masih belum terbentuk rasa tolerannya terhadap pelajar yang melakukan aktifitas belajar. Hal tersebut dapat dilihat dari aktivitas yang dilakukan oleh anggota keluarga lain yang masih kerap menonton televisi pada Jam Wajib Belajar. Kesimpulan tersebut dapat diperkuat dengan melihat jawaban dari para narasumber mengenai acara favorit yang kerap ditonton oleh anggota keluarga. Dimana sebagian besar dari narasumber menjawab dengan jawaban Sinetron Anak Jalana, Uttara, D'Academi dan acara-acara lain. Jawaban tersebut menunjukkan bahwa memang mereka mengetahui secara langsung acara yang kerap ditonton oleh anggota keluarga lain disaat dia sedang melakukan aktifitas belajar atau saat Jam Wajib Belajar sedang berlangsung.

Oleh karena itu, dengan mengacu pada pendapat yang diungkapkan oleh Van Doorn (2014, hlm. 905) yang mengatakan bahwa, "tolerance entails acceptance of the very things one disagrees with, disapproves of or dislikes. Tolerance can be seen as 'a flawed virtue' because it concerns acceptance of the differences between others and ourselves that we would rather fight, ignore, or overcome".
Sehingga dengan memanfaatkan Program Jam Wajib Belajar ini, peneliti berharap dapat meningkatkan toleransi masyarakat Kota Mojokerto dengan cara menerima sesuatu yang menurutnya itu tidak menyenangkan seperti, mematikan televisi, radio, serta melakukan hal-hal lain yang dapat mengganggu konsentrasi anak saat melakukan aktifitas belajar saat Jam Wajib Belajar sedang berlangsung, menjadi sesuatu yang mampu mereka terima demi tercapainya kehidupan yang berdampingan, damai, dan terciptanya Kota Mojokerto yang lingkungan pendidikan.

Disamping itu menurut Wilson (2014, hlm. 852) toleransi juga secara intrinsik dapat dikembangkan melalui hubungan alternatif saat diposisikan sebagai "perjuangan" guna memperluas cara berpikir dan bertindak setiap individu dalam masyarakat. Selain itu menurut Schirmer, Weidenstedt dan Reich (2012, hlm. 1052), "whilst tolerance might be a required minimum of social interaction, stagnancy on that level involves a life without dignity". Lebih lanjut, Bruner (2015, hlm. 429) berpendapat bahwa walaupun pada awalnya individu cenderung tidak mau bekerjasama dengan orang-orang yang jauh berbeda dengan diri mereka. Namun seiring dengan berjalannya waktu memungkin rasa toleran tersebut untuk terbentuk, sehingga pada akhirnya semua akan menuai keuntungan dari kerjasama dan rasa toleran yang dimiliki.

Berdasarkan berbagai argumen dari hasil riset tersebut, maka peneliti sangat mendukung agar berbagai kebijakan dan program yang dikeluarkan oleh pemerintah kedepannya juga dapat bertujuan guna meningkatkan toleransi dan interaksi sosial seluruh anggota masyarakatnya, sehingga terciptalah rasa saling menghormati, menerima dan kesetaraan antar anggota masyarakat. Seingga pada akhirnya, sesuai dengan pendapat Bruner, bahwa kerjasama dan rasa toleran tersebut akan memberikan 
keuntungan kepada setiap anggota masyarakat.

Civic disposition yang keempat yang berusaha dibentuk melalui Program Jam Wajib Belajar yakni kepedulian. Dimana Swanson (1991 dalam Potter \& Perry 2009) mendefinisikan kepedulian sebagai suatu cara pemeliharaan hubungan dengan saling menghargai orang lain, disertai perasaan memiliki dan tanggung jawab. Menurut Swanson (2000) terdapat lima dimensi penting dalam kepedulian.

1) Mengetahui (knowing). Berusaha keras memahami kejadian-kejadian yang memiliki makna dalam kehidupan orang lain. Pada aspek ini menghindari asumsi tentang kejadian yang dialami orang lain sangat penting, berpusat pada kebutuhan orang lain, melakukan penilaian yang mendalam, mencari isyarat verbal dan non verbal, dan terlibat pada kedua isyarat tersebut.

2) Turut hadir (being with). Hadir secara emosi dengan menyampaikan ketersedian, berbagi perasaan, dan memantau apakah orang lain terganggu atau tidak dengan emosi yang diberikan.

3) Melakukan (doing for). Melakukan sesuatu bagi orang lain, seperti melakukannya untuk diri sendiri, apabila memungkinkan, seperti menghibur, melindungi, dan mendahulukan, seperti melakukan tugas-tugas dengan penuh keahlian dan kemampuan.

4) Memungkinkan (enablings). Memfasilitasi perjalanan hidup dan kejadian yang tidak biasa yang dimiliki oleh orang lain dengan memberikan informasi, memberikan penjelasan, memberikan dukungan, fokus pada perhatian yang sesuai, dan memberikan alternatif.

Mempertahankan keyakinan (Maintaining confidence). Mendukung keyakinan orang lain akan kemampuannya menjalani kejadian atau masa transisi dalam hidupnya dan menghadapi masa yang akan datang dengan penuh makna. Tujuan tersebut untuk memungkinkan orang lain dapat memaknai dan memelihara sikap yang penuh harapan.

Berdasarkan pendapat yang diungkapkan oleh Swanson terkait dengan pengertian dan kelima dimensi penting dalam kepedulian, peneliti melakukan teknik pengambilan data melalui kuesioner dengan 29 narasumber yang berstatus sebagai pelajar aktif di Kota Mojokerto dan juga berdomisili di Kota Mojokerto. Pertanyaan dasar yang digunakan peneliti dalam mengetahui kepedulian orang tua, anggota keluarga dan masyarakat terkait dengan Program Jam Wajib Belajar adalah melalui pengetahuan pelajar mengenai program dan sumber informasi terkait dengan program tersebut. Pertanyaan lanjutan yang digunakan oleh peneliti adalah terkait dengan keberadaan orang tua maupun anggota keluarga yang kerap menemani atau membatu mereka saat mengalami kesulitan.

Melalui hasil kuesioner terkait dengan pertanyaan mengenai pengetahuan pelajar tentang Program Jam Wajib Belajar dan sumber informasi terkait dengan program tersebut, peneliti mendapatkan kesimpulan bahwa sebagian besar yakni 96,5\% dari narasumber yang berjumlah 29 pelajar ini telah mengetahui tentang Program Jam Wajib Belajar yang diadakan oleh Pemerintah Kota Mojokerto. Sumber informasi yang diperoleh memang sangat beragam, yakni dari orang tua sebesar $28,6 \%$, dari sekolah sebesar $21,5 \%$, dari pak Rt sebesar $17,9 \%$, dari stiker $14,2 \%$, dari pemerintah $10,7 \%$, dan sisanya sebesar $17,9 \%$ berasal dari tiga sumber lain yakni saudara, masjid dan spanduk.

Hasil tersebut menunjukkan bahwa dimensi kepedulian yang keempat dan kelima dari Swanson yakni memungkinkan (enablings) dan mempertahankan keyakinan (Maintaining confidence) tersebut telah terbentuk. Hal tersebut dapat dibuktikan dengan kesediaan orang tua, 
anggota keluarga maupun masyarakat dalam memberikan fasilitas, meluangkan waktu, tenaga dan pengorbanan lain demi memberikan informasi, memberikan penjelasan, serta memberikan dukungan kepada para pelajar terkait dengan Jam Wajib Belajar, dan manfaat yang akan diperoleh jika melakukan kegiatan belajar.

Selanjutnya terkait dengan keberadaan orang tua maupun anggota keluarga yang kerap menemani atau membantu mereka saat mengalami kesulitan dalam belajar, diperoleh kesimpulan bahwa sebanyak $79,3 \%$ atau sebanyak 23 dari 29 jumlah total narasumber menyatakan kalau ada anggota keluarga yang menemaninya saat sedang melakukan aktifitas belajar. Anggota keluarga yang kerap menemani atau membatu mereka saat mengalami kesulitan yakni kakak atau orang tua.

Keterlibatan orang tua yang dalam hal ini adalah ibu, dalam pendidikan seorang anak memang tidak dapat dipandang remeh. Berdasarkan riset yang dilakukan oleh Panda (2015, hlm. 2019) bersama dengan 75 ibu di Negara India, diperoleh hasil bahwa pendidikan sekolah yang dipandang sebagai dasar pendidikan anak guna mencapai karir profesional di masa depan juga sebagian besar bergantung pada peran ibu bersama dengan faktor penting lainnya. Lebih lanjut Lauren (1987, hlm. 73) berpendapat bahwa keterlibatan ibu dalam pendidikan anak di sekolah anaknya, dapat memotivasi anak menuju kesuksesan sekolah

Sehingga kesimpulan yang diperoleh berdasarkan hasil data temuan dan berbagai pendapat tersebut, menunjukkan bahwa dimensi yang yang pertama, kedua dan ketiga dari Swanson terkait dengan mengetahui (knowing), turut hadir (being with), serta melakukan (doing for) juga telah dapat terbentuk melaui Program Jam Wajib Belajar ini. Jadi dengan terbentuknya kelima dimensi kepedulian tersebut, maka dapat disimpulkan bahwa karakter kepedulian merupakan salah satu karakter yang dapat dibentuk dan dikembangkan melalui Program Jam Wajib Belajar yang diterapkan di Kota Mojokerto.

\section{SIMPULAN DAN SARAN \\ 4.1. Simpulan}

Berdasarkan hasil temuan, analisis hasil dan pembahasan, peneliti dapat menyimpulkan bahwa:

1. Pembentukan civic disposition warga negara khususnya di kota mojokerto melaui program jam wajib belajar telah terlaksana dengan baik. pembentukan tersebut dilakukan melalui berbagai tahapan yakni sosialisasi, penyuluhan, dan pemantauan secara langsung.

2. civic disposition yang dapat dibentuk melalui program jam wajib belajar yakni karakter disiplin dan peduli. sedangkan karakter lain seperti tanggung jawab dan toleran masih belum dapat terbentuk secara sempurna melalui program jam wajib belajar hingga saat ini.

\subsection{Saran}

Berdasarkan pada kesimpulan di atas, peneliti memberikan beberapa rekomendasi yang ditujukan pada pemerintah, masyarakat serta pelajar untuk memperhatikan hal-hal sebagi berikut:

1. Peneliti menyarankan kepada pemerintah untuk membuat berbagai inovasi yang dapat meningkatkan manfaat dari Program Jam Wajib Belajar ini. Salah satu inovasi yang dapat dilakukan oleh pemerintah yakni dengan mengadakan pemantauan secara langsung (diluar kegiatan sidak) agar pemerintah bisa mengetahui kegiatan masyarakat secara nyata.

2. Diharapkan masyarakat Kota Mojokerto mampu lebih meningkatkan partisipasinya dalam membentuk civic disposition melalui 
Program Jam Wajib Belajar. Salah satu partisipasi yang sangat sepele namun dalam kenyataannya paling banyak dilanggar adalah mematikan televisi saat Jam Wajib Belajar sedang berlangsung.

3. Saran yang peneliti tujukan kepada para pelajar, khususnya di lingkup Kota Mojokerto adalah jangan hanya belajar karena takut mendapatkan sanksi, melainkan belajarlah karena manfaat yang akan diperoleh dari aktifitas tersebut. Selanjutnya dalam melaksanakan Program Jam Wajib Belajar diharapkan pelajar juga mampu berperan secara aktif dalam tercapainya tujuan dari program tersebut, salah satunya yakni dengan belajar pada waktunya maupun mengajak teman yang belum secara intens melakukan kegiatan belajar untuk belajar bersama-sama.

\section{DAFTAR PUSTAKA}

Austin, O. O, dan Omomia, T. A.. (2014). Relevance of Skinner's Theory of Reinforcement on Effective School Evaluaution and Management. Russian Federation European Journal of Psychological Studies, 4 (4), hlm. 174-180.

Berger, J., dan Hevenstone, D. (2016). Norm enforcement in the city revisited: An international field experiment of altruistic punishment, norm maintenance, and broken windows. Journal of Rationality and Society. Sage Publication, hlm. 1-21.

Bruner, J. P. (2015). Diversity, Tolerance, and The Social Contract. Journal of Politics, Philosophy \& Economics. Sage Publication, 14 (4), hlm. 429448.

Cangara, H. (2005). Pengantar Ilmu Komunikasi. Jakarta: PT Raja Grafindo Persada.

Cholisin. 2011. Pengembangan Karakter Dalam Materi Pembelajaran PKn. Disampaikan pada kegiatan MGMP PKn SMP Kota Yogyakarta, 18 Januari 2011; Staf Pengajar Jurusan PKn \& Hukum FISE UNY.
Fried, A. (2011). Learning Organizations Without Borders? A cross-cultural Study of University HR Practitioners' Perceptions of the Salience of Senge's Five Disciplines in Effective Work Outcomes. International Journal of Cross Cultural Management, 12 (1), hlm. 101-114

Griffith, K. G. dan Hamza, M. K. (2006). You Can Lead A Horse to Water but Can You Make Him Think? Human Cognition's Impact on How Well Our Administrators Can Jungle The management of Human performance in Today's schools. National Forum of Educational Administration and Supervision Journal, 23, hlm. 4.

Hardin, M. G, dkk. (2005). Reward and Punishment Sensitivity in Shy and Non-shy Adults: Relations Between Social and Motivated Behavior. Journal of Personality and Individual Differences, 40, hlm. 699711.Kemdiknas, 2011, hlm. 8

Ihsan, F. (2007). Dasar-dasar Kependidikan. Jakarta: Rineka Cipta. 
Kneedler, A. D., Coleman, S. S., dan Ingraham, P. W. (2000). Measuring Government Management Capacity: A Comparative Analysis of City Human Resources Management Systems. Oxford University Press on behalf of the Journal of Public Administration Research and Theory, 10 (2), hlm. 381-412.

Kwon, I. (2014). Motivation, Discretion, and Corruption. Oxford University Press on Behalf of The Journal of Public Administration Research and Theory, 24 (3), hlm. 765-794.

Lauren, A. (1987). Social Class Difference in Family-School Relationships: The Importance of Cultural Capital. Journal Sociology of Education, 60 (2), hlm. 73-85.

Lickona, T. (2004). Character Matters. New York: Somon \&. Schuster.

Mar'at. (1994). Pimpinan Dan Kepemimpinan. Jakarta: Ghalia Indonesia.

Maunah, B. (2009). Ilmu Pendidikan. Yogyakarta: Teras

Milles, B. M. \& Huberman A. M. (2007). Analisis Data Kualitatif: Buku Sumber Tentang Metode-Metode Baru. Jakarta: PT Gramedia.

Nassima, B. dan Souheyla, B. (2014). Reward and Punishment Processing in Depression. International Journal of Humanities Social Sciences and Education (IJHSSE), 1 (6), hlm. 6368.

Ningsih, R. (2006). Pendidikan Kewarganegaraan untuk Kelas 2 SD. Jakarta: Yudhistira.

Panda, G. (2015). Maternal Involvement in Everyday Schooling: A Micro Study.
Indian Journal of Gender Studies. Sage Publication, 22 (2), hlm. 219242.

Peraturan Walikota Mojokerto Nomor 17 Tahun 2009. Tentang Petunjuk Pelaksanaan Program Kota Mojokerto Berlingkungan Pendidikan (PKMBP).

Potter, P. A. dan Perry, A.G. (2009). Fundamental Keperawatan Buku 1. Ed. 7. Jakarta: Salemba Medika.

Rose, C. dan Nicholl, M. J. (2003). Accelerated Learning For The 21st Century: Cara Belajar Cepat Abad XIXII. Jakarta: Nuansa.

Sardiman. (2007). Interaksi dan Motivasi Belajar Mengajar. Jakarta: Rajagrafindo Persada.

Schirmer, W., Weidenstedt, L., dan Reich, W. (2012). From Tolerance to Respect in Inter-ethnic Contexts. Journal of Ethnic and Migration Studies, 38, hlm. 1049-1065.

Shannon, C.E. (1948). A mathematical theory of communication. Bell Syst. Teaching Journal, 27, hlm. 379-656.

Snyder, C. R. (1994). The Psychlology of Hope: You Can Get There from Here. New York: Free Press.

Snyder, C. R., Shorey, H. S., dkk. (2002). Hope and Academic Success in College. Journal of Educational Psychology, 94 (4), hlm. 820-826.

Suwarno, H. (1985). Administrasi Pemerintahan Dalam Pembangunan Nasional. Jakarta: PT.Gunung Agung.

Swanson, E. R. (2000). Working With Other Disciplines. American Journal of Agriculral Economic, 4, hlm. 34170. 
HUMANIKA Vol. 23 No. 1 (2016) ISSN 1412-9418

Program Jam Wajib Belajar Dalam Membentuk Civic Disposition Warga Negara Nastiti Mufidah

Syukur, A. (1987). Kumpulan Makalah "Study Imlementasi Latar Belakang Konsep Pendekatan dan Relevansinya Dalam Pembangunan”. Ujung Pandang: Persadi.

Van Doorn, M. (2014). The Nature of Tolerance and The Social Circumstances in Which It Emerges. Journal of Current Sociology. Sage Publications, 62 (6), hlm. 905-927.
Wilson, H. F. (2014). The Possibilities of Tolerance: Intercultural Dialogue in A Multicultural Europe. Journal of Environment and Planning D: Society and Space, 32, hlm. 852-868.

Zamroni. (2011). Pendidikan Demokrasi pada Masyarakat Multikultural. Yogyakarta: Gavin Kalam Utama. 